OPEN ACCESS

Edited by:

Metodi Sotirov,

University of Freiburg, Germany

Reviewed by:

Jan Börner

University of Bonn, Germany

Giuliano Maselli Locosselli,

University of São Paulo, Brazi

*Correspondence:

Marcelo C. C. Stabile

marcelo.stabile@ipam.org.br

Specialty section: This article was submitted to

Tropical Forests,

a section of the journa

Frontiers in Forests and Global

Change

Received: 30 November 2020

Accepted: 21 December 2021

Published: 09 February 2022

Citation:

Stabile MCC, Garcia AS,

Salomão CSC, Bush G,

Guimarães AL and Moutinho P (2022)

Slowing Deforestation in the Brazilian

Amazon: Avoiding Legal Deforestation

by Compensating Farmers

and Ranchers.

Front. For. Glob. Change 4:635638.

doi: 10.3389/ffgc.2021.635638

\section{Slowing Deforestation in the Brazilian Amazon: Avoiding Legal Deforestation by Compensating Farmers and Ranchers}

Marcelo C. C. Stabile ${ }^{1 *}$, Andrea S. Garcia', Caroline S. C. Salomão', Glenn Bush², André L. Guimarães ${ }^{1}$ and Paulo Moutinho ${ }^{1}$

${ }^{1}$ Amazon Environmental Research Institute (IPAM), Brasilia, Brazil, ${ }^{2}$ Woodwell Climate Research Center, Falmouth, MA, United States

The Amazon Forest is an unquestionable cradle of planetary biological diversity and plays a fundamental role in regional and global climate change regulation. Annual deforestation rates in the Brazilian Amazon have gone up since 2012, presenting a grim scenario for 2021. The majority of this deforestation is illegal, but a significant proportion, 11.3 million hectares of forest in privately owned land, can be legally deforested and impact local climate, compromising Brazil's Nationally Determined Contribution (NDC) to the Paris Agreement. Thus, a fundamental question remains: how can we avoid potentially legal deforestation? Farmers and ranchers who have the right to deforest have long demanded financial incentives to keep their forests standing, but few (if any) mechanisms exist to achieve it. We developed a compensation mechanism called CONSERV, hypothesizing that legal deforestation can be avoided through targeted compensation. CONSERV can potentially contribute to climate change mitigation and foster business models geared towards conservation and increased agricultural productivity when implemented at scale. We present CONSERV's concept and potential to become an operational mechanism for Payment for Ecosystem Services/REDD + in line with Brazil's Native Vegetation Protection Law and NDC commitment. Furthermore, we introduce some ideas on how CONSERV ensures permanence and minimizes leakage while gaining scale. To successfully maintain climatic stability and ecosystems, we need to reduce deforestation, both illegal and legal. CONSERV can help us solve the latter.

Keywords: avoided deforestation, Amazon, financial mechanism, targeted compensation, CONSERV

\section{INTRODUCTION}

The Brazilian Amazon houses the world's largest tropical forest, hosting 10\% of the world's biodiversity (Cavender-Bares et al., 2018), and contributing to global climate change mitigation by retaining large carbon stocks (Phillips et al., 2017; Gatti et al., 2021). The forest is also responsible for providing the rain that a large proportion of the Brazilian agricultural sector 
relies on (Sampaio et al., 2007; Spera et al., 2016; Rizzo et al., 2020; Leite-Filho et al., 2021). Despite these benefits, deforestation rates in the Legal Amazon are once again on the rise. Since 2012, when the annual deforestation rate was $4,571 \mathrm{~km}^{2}$, deforestation in the region has increased by $120 \%$, reaching $10,851 \mathrm{~km}^{2}$ in 2020 (Instituto Nacional de Pesquisas Espaciais [INPE], 2021). The rate for 2021 is predicted to be even higher, with more than $16.000 \mathrm{~km}^{2}$ of deforestation alerts from January to October 2021 in the Legal Amazon (Instituto Nacional de Pesquisas Espaciais [INPE], 2021). Most of the deforestation is not authorized, with over $90 \%$ of deforested properties doing so illegally (Azevedo et al., 2017; MapBiomas Alerta, 2020; Rajão et al., 2020; Vasconcelos et al., 2020). Nevertheless, according to Brazil's Native Vegetation Protection Law (hereafter referred to as NVPL) (Brasil, 2012), many private forested areas can still be deforested legally. The NVPL imposes special restrictions on rural properties in the Legal Amazon - a group of nine states hosting the entire portion of the Amazon biome in Brazil and part of the Cerrado biome, transitioning to forest as it approaches the Amazon biome. Properties in savanna ecophysiognomies must maintain $35 \%$ of the property as native vegetation cover while properties in forest ecophysiognomies must maintain $80 \%$ as so-called "Legal Reserves" (LR). Independently of the LR requirement, properties also are required to maintain the native vegetation around water bodies, varying in size according to the water body type and size - these areas are the Permanent Preservation Areas (hereafter referred to as PPA). The area of native vegetation in these properties beyond the LR and PPA can be legally deforested if licensed by the state's environmental agencies; this portion is defined as native vegetation assets.

These assets available for legal deforestation are mainly concentrated along the agricultural frontier, where expansion is primarily promoted. Legal deforestation is still observed within consolidated regions on a smaller scale. Nevertheless, the amount of native vegetation with the potential to be legally cleared has not yet been precisely determined.

In this paper, we estimate the total area of native vegetation surplus in the Brazilian Legal Amazon (hereafter referred to as the Amazon). We also propose an innovative payment concept for ecosystem services - CONSERV - to compensate those landowners willing to give up their legal right to deforest. To demonstrate how CONSERV could be operationalized, we describe on how it has been implemented - on a pilot scale - in the state of Mato Grosso, Brazil. We expect the program to be scaled up with the development of a business model, possibly more than one. Participation of landowners in CONSERV is voluntary but governed by wellestablished legal institutions (national and state contract law and traditions) between private landowners and emerging markets for carbon sequestration and other ecosystem services. In addition, participation in CONSERV can represent added value for farm enterprises through preferential access to markets as global and national sustainable supply chain efforts evolve to focus on compliance with environmental and social governance standards.

\section{ESTIMATING AREAS AVAILABLE FOR LEGAL CONVERSION AND ASSOCIATED AVOIDED EMISSIONS}

We estimated the area at risk of legal deforestation by modeling the native vegetation assets in private rural properties according to the NVPL (Brasil, 2012). Our model receives three inputs: a rural property mesh, a hydrological mesh representing rivers, and a deforestation layer. The rural properties mesh is a compilation of land tenure (Instituto Nacional de Colonização e Reforma Agrária [INCRA], 2021) and the Rural Environmental Registry (CAR Portuguese acronym - Serviço Florestal and Brasileiro [SFB], 2021). The CAR is an instrument proposed in the 2012 revision of the forest code which mandates that farmers register their property boundaries and areas of LR and PPA in a public registry called SICAR. Any property overlapping areas with any tenure conflict with public land, such as undesignated public lands, indigenous lands, public protected areas, traditional land "quilombolas," rural settlements, or military areas, is excluded. The hydrological mesh is a compilation of simple river representation from different sources, prioritizing those built at a finer scale (Agência Nacional de Águas [ANA], 2018; Fundação Brasileira and Desenvolvimento Sustentável [FBDS], 2021). The deforestation layer is derived from PRODES data for the Amazon and Cerrado (Instituto Nacional de Pesquisas Espaciais [INPE], 2021), and MapBiomas land cover layers (MapBiomas, 2020).

For each property, we calculated the total area, the remaining native vegetation area, the PPA (using a default width of $30 \mathrm{~m}$ around rivers), the LR according to the proportion of different ecophysiognomies on the property, and native vegetation assets as a difference between property area and the sum of LR and PPA areas. We also estimated the carbon stocks above ground within the native vegetation assets using the spatially referenced data from the fourth Brazilian carbon inventory (MCTI, 2021). The carbon stocks were calculated by multiplying the carbon density in the remaining native vegetation by the assets in each property throughout the states of the Brazilian Amazon.

We estimate that a total of 11.3 Mha of native vegetation in private properties in the Legal Amazon represents assets which could be legally deforested (Figure 1). The state of Mato Grosso alone hosts 3.1 Mha of these assets. The results for the Brazilian Amazon were lower when compared to other studies, which indicated an area of native vegetation beyond LR and PPA ranging from $\sim 21$ to $\sim 38 \mathrm{Mha}$ in the same region (Soares-Filho et al., 2014; Rajão et al., 2020; Observatório do Código Florestal $[\mathrm{OCF}], 2021)$. This difference can be explained by the fact that we excluded from our analysis any property overlapping with public lands, but also due to our restriction of defining assets exclusively as native vegetation that could legally be deforested. The NVPL creates few mechanisms to reduce the required LR if it is deforested already, and some studies model the LR surplus as native vegetation in a property beyond these reductions. However, such surpluses cannot necessarily be legally deforested today. Nevertheless, asset estimates are likely to change over time due to deforestation (reducing assets) or through a mechanism in the NVPL which, if implemented, would reduce the general rule 


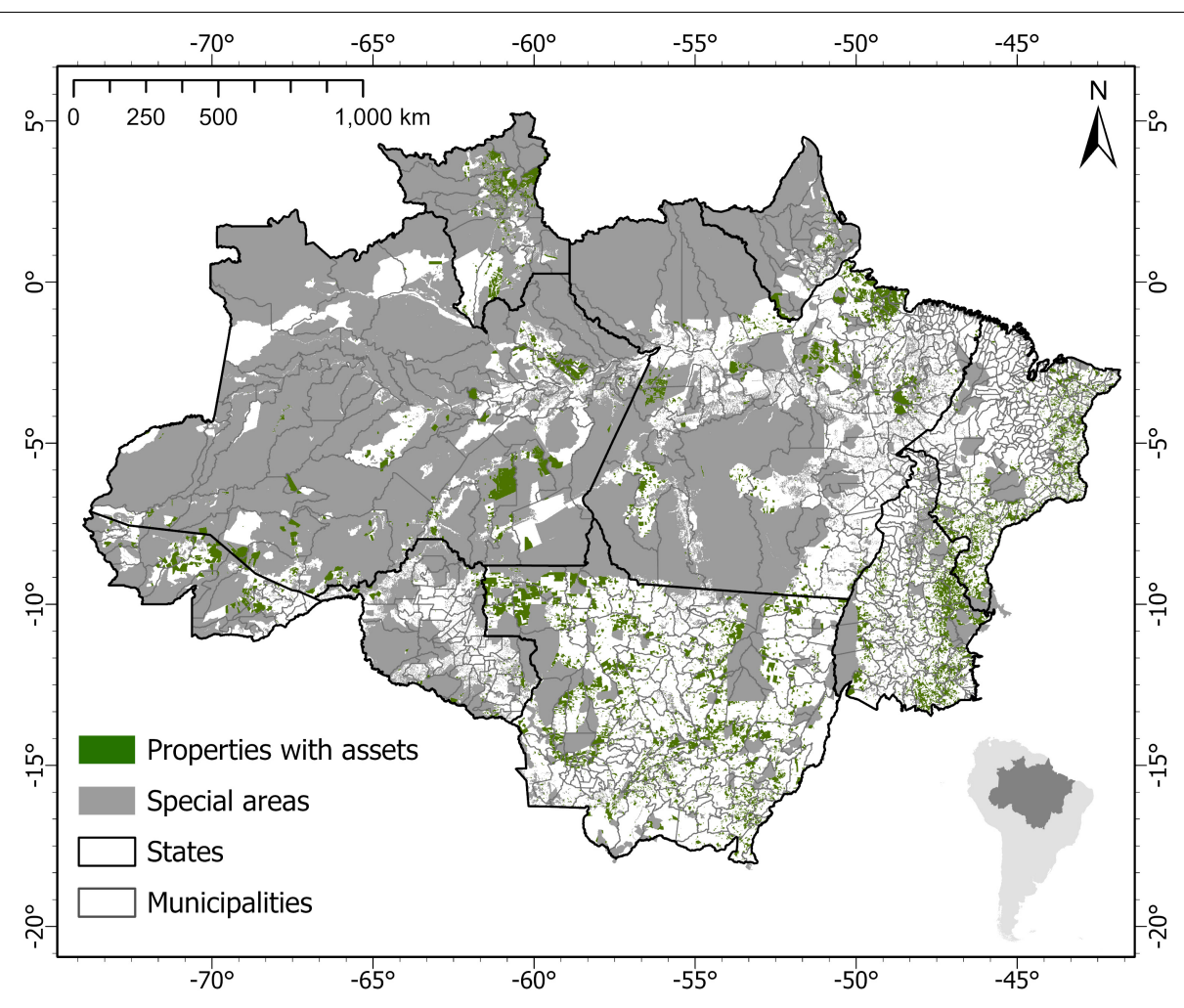

FIGURE 1 | Distribution of properties with native vegetation assets in the Legal Amazon states. Assets are the remaining native vegetation in private rural properties beyond what are required for Legal Reserves and Permanent Preservation Areas, and which can be legally deforested.

of LR requirements in certain regions to $50 \%$ of the properties in forest areas. Freitas et al. (2018) have estimated this mechanism could increase the assets in the Amazon by between 6.5 and 15.4 million hectares.

The carbon stock of these native vegetation assets equates to $474 \mathrm{Mt}$ of above ground carbon stocks for the Brazilian Amazon and 126.1 MtC for the state of Mato Grosso. If all this native vegetation were to be legally deforested, it would release to the atmosphere around $1,738 \mathrm{MtCO}_{2} \mathrm{e}$, and 462.6 $\mathrm{MtCO}_{2} \mathrm{e}$, respectively. This would amount to $110 \%$ of liquid Brazilian emissions in 2019 across all sectors (1,570,912,809 $\mathrm{tCO}_{2} \mathrm{e}$ ), according to Albuquerque et al. (2020). Such assets are at risk of legal deforestation since they are not protected by public policy, as long as the property being registered within the CAR is able to obtain a license.

\section{REDUCING LEGAL DEFORESTATION: THE CONSERV CONCEPT}

To avoid the legal deforestation of 11.3 Mha in the Brazilian Amazon, we proposed CONSERV. The concept of CONSERV was developed as a 3 year pilot experiment, beginning in 2020. In its first stage, we will contract 20,000 ha of native vegetation assets distributed among 20-30 farms in three different locations within the Amazon; currently, we have contracted 9 farms totaling 8,410 ha under conservation. To join CONSERV, farmers must be in full compliance with the existing legislation and are monitored quarterly, being penalized if contract conditions are not met. Monitoring is crucial to ensure that the native vegetation is being conserved.

The CONSERV concept aims to contribute to a new paradigm based on the recognition that standing forests have an intrinsic value due their provision of ecosystem services and biodiversity maintenance. Their value thus needs to be recognized by market actors and become a revenue stream for rural landowners. In implementing CONSERV, we expect to develop, discuss and test different business models to establish this new paradigm. Additionally, CONSERV emerges as a private mechanism which is simple, as it targets areas not protected by law; agile, in comparison to bureaucratic public services in the environmental arena in Brazil; and voluntary, which enables farmers to willingly join.

\section{Prioritizing Locations With Forest Assets}

There is a predefined process for CONSERV operationalization on the ground. We combine a series of variables for the selection of locations, where at a municipality level we compute the areas available for legal conversion, along with indicators of environmental services, deforestation pressure and a model of opportunity cost of forgone alternative agricultural activities as an indicator of compensation value. Through this procedure, we identify the areas most likely to be converted, with higher provision of environmental services and where the costs are 
not prohibitive. We then select areas that provide us the best value in terms of environmental benefits by dollar spent. We, thus, select these priority areas to start on-site operations. This approach, which aims to align the assessment of opportunity costs and environmental service provision with land tenure guarantees, has been recognized in the literature for producing cost-effective results (Chomitz et al., 2004; Börner et al., 2017).

Subsequently, we engage local stakeholders to present the project and its characteristics, allowing producers to voluntarily apply for the program. Land owners can apply to the CONSERV initiative by submitting a letter of interest along with supporting documents which are used to evaluate legal compliance. The state government is not directly involved, however, it does provide CONSERV with public data which is used during the due diligence procedure. During this procedure we ensure that the applicant (i) is the legal owner of the land and the areas that can be legally converted, (ii) is not in conflict with environmental and social regulations, and (iii) has no criminal offenses on record. All these aspects are analyzed by comparing the documentation submitted by the applicant with open databases made available by the Brazilian government. Legal ownership is analyzed against a land tenure dataset (both public and private land), while environmental and social compliance is assessed by searching for legal actions against the applicant in regard to environmental crimes on the state and federal level. We require registration in the CAR system, exclude properties which overlap with protected areas or traditional communities (both indigenous and "quilombolas") and search for violations of environment and labor regulations, including modern slavery. This verification is not only conducted for the candidate property, but for all partners involved in the ownership; as a consequence, we can capture leakage processes linked to the legal owners.

\section{Contracting, Monitoring and Paying}

Follow up communication with land owners is carried out to clarify and update the information submitted, and they can join CONSERV once the screening process is concluded. Farm selection is done considering a combination of factors, including willingness to join, compliance with the program criteria and an analysis of candidate properties to determine which will deliver the best environmental outcomes. Prices are individually negotiated and set, being influenced by different factors, such as opportunity cost, carbon stock and other ecosystem services, as well as deforestation risk. Eventually, reverse auction will be tested as a pricing methodology in which farmers compete for compensation among themselves and, thus, prices trend down as the bidding goes on. A private contract bound by Brazilian law is signed between CONSERV and land owners, and both partners have obligations and penalties for non-compliance.

Once the properties have joined CONSERV, they are monitored quarterly and reports on the status of the contracted areas are generated. Payments are conditional upon prior verification of contract requirements, including monitoring of native vegetation and all compliance aspects analyzed upon applying for CONSERV.

\section{Impact Evaluation and Effectiveness}

A robust impact monitoring system is central to establishing and maintaining the program's long term credibility in terms of additionality and permanence of forest carbon, as well as reporting on environmental and social governance performance standards. CONSERV is in a pilot phase and since establishment has contracted 9 farms into its program, with more than 20 others currently in varying stages of the application process. As such, it has not yet been possible to conduct a robust impact assessment (e.g., full randomized control experiment). CONSERV will adopt a quasi-experimental approach to biophysical forest monitoring, comparing deforestation baselines established ex ante in participants farms, to counterfactuals constructed ex post based on the synthetic control method (West et al., 2020). The approach is a good fit to the CONSERV context, unlike more traditional methods from the impact evaluation literature (e.g., difference-in-differences estimator), because of our small number of treated units and likely heterogeneity of the treatment across them (Rubin, 1974; Rosenbaum and Rubin, 1983; Abadie et al., 2015). Synthetic controls will be constructed as a weighted average of selected "donor" units through a nested optimization procedure, such that the resulting weighted average outcome of the selected donor units closely matches the pretreatment outcome in the treated unit (Abadie et al., 2010).

In CONSERV, to understand the eventual impact on participating farmers, as well as their compliance with the program operating standards, a beneficiary contact monitoring approach is applied. This includes a baseline survey of participants upon joining the program, regular monitoring surveys and, upon the contract conclusion, an exit survey to determine and evaluate changes to participants' knowledge, attitudes and practices towards conservation and climate change, farm enterprise management and experiences with evolving management practices.

Furthermore, at the end of the contract period, for ex post evaluation of social and economic impacts, we will randomly evaluate contracted properties against control properties, testing the effectiveness of the mechanism (Jayachandran et al., 2017). In the meantime, we are developing different business models with the private sector to enable mechanisms such as CONSERV to gain scale and become a market mechanism to avoid legal deforestation.

\section{DISCUSSION}

Payment for Environmental Service (PES) initiatives are subject to numerous uncertainties (Bleischwitz et al., 2017) that relate to the impact and effectiveness of these programs. One of these is due to the complexity of human-environment systems (HES) (Barnaud and Antona, 2014). Clearly, PES programs interact with preexisting social-ecological systems and policy frameworks in ways that are rarely well enough understood (Börner et al., 2017). Moreover, because HES are multi-scalar, i.e., they are temporally dynamic and spatially distributed (Liu et al., 2015), they are subject to different time, frequency, amplitude, and scale dynamics. 
We have determined that the Legal Amazon hosts 11.3 Mha of native vegetation assets available for legal deforestation, corresponding to $1,738 \mathrm{MtCO}_{2} \mathrm{e}$, and have proposed a mechanism designed to avoid the deforestation of such assets.

Deforestation and its associated emissions represent a challenge for Brazil in meeting its NDC and making significant contributions to global climate change mitigation. Brazil's NDC (Brasil, 2015) presented at the 21st Conference of Parties to the UN Framework Convention on Climate Change determined that the country would reduce its annual $\mathrm{CO}_{2}$ emissions to $1.3 \mathrm{GtCO}_{2} \mathrm{e} /$ year by 2025 . This value is equivalent to75\% of the estimate $\mathrm{CO}_{2}$ above the ground in the calculated assets, demonstrating how important it is to avoid legal deforestation not only from the perspective of Brazil's NDC, but also to mitigate climate change at the global (Coe et al., 2017) and local levels (Silvério et al., 2015).

We expect that CONSERV can serve as an inductor, a lever to stimulate the debate around PES regulation and other incentives for landowners to protect forests within their properties. In parallel, CONSERV can be used as an operational tool for meeting Environmental Conversation Quotas (CRA, in Portuguese) included in the NVPL, or to implement the PES mechanism that was approved in Congress (Brasil, 2021); both are not yet regulated. From a private perspective, it can also be used as a tool to generate credible, verifiable and high-integrity carbon credits within a jurisdictional setup in the Amazon states. Furthermore, it can also be used to provide sustainable, zero-conversion commodities, which have seen an increase in market demand. Investors can allocate capital upfront, accepting lower returns with increased environmental outcomes, or carbon credits, for instance. Such models are being discussed and developed as we test CONSERV on the ground.

At the international level, it is also necessary to approve the Paris Agreement's Article 6 on forest offsets in a way that cooperation through carbon markets can bring additional public and private financing, catalyzing emissions reductions in a country hosting the mitigation activity. Voluntary carbon markets mobilized $104 \mathrm{MtCO}_{2} \mathrm{e}$ in 2019, a 6\% increase compared to 2018. In 2019, despite the lower volume, the market value of AFOLU offsets was more than twice that of Renewable Energy, and demand for offsets associated with forest management in developing countries (i.e., REDD+) remains especially strong (Donofrio et al., 2020).

The use of carbon markets, voluntary or preferably regulated under a jurisdictional setup, will allow for the use of forest carbon offsets from countries such as Brazil, helping to increasing emitting countries' ambition. This will allow for resource investment in forest conservation, targeting both legal (through innovative mechanisms) and illegal deforestation (improved command and control). Mechanisms like CONSERV can contribute substantially, both to protecting tropical forests beyond the Amazon, and to engaging landowners in conservation efforts, in addition to stimulating a new economic model for farms, which includes standing forests as a revenue stream. Together, these incentives represent an important contribution to climate change mitigation.
However, there are many challenges facing CONSERV, such as the engagement and recruitment of farmers and contract negotiations at scale, where mechanisms such as reverse auctions can and must be used. Leakage can be minimized through due diligence procedures on the part of landowners and constant monitoring. Monitoring of the contracted areas is a challenge eased by technological innovation, where the contracted areas can be closely monitored remotely. Implementing MRV is also important to ensure that processes and procedures are being followed and that the contracted areas are kept standing. Innovative models that value native vegetation, not only for its carbon stock, but also for the embedded environmental services (biodiversity, climate regulation, etc.), must be developed to ensure the permanence in these areas of native vegetation.

Such models must involve private resources from the markets and people that benefit from more sustainable commodities contributing to climate change mitigation. New financial markets must be developed which consider native vegetation assets in the equation, such as using these assets as collateral in agricultural loans, or as guarantees. These forest assets can also be used to reduce insurance premiums for the farmer, or to grant concessional loans to farmers with assets, provided they invest in agricultural intensification. Lastly, retail and the meatpacking industry could also provide premiums to farmers with assets, recognizing their role in sustainable production and reducing the company's reputational risks. Through further developing these ideas, CONSERV's impact can be significantly enhanced.

Landowners have long complained about the lack of incentives to keep their forests standing. Native vegetation areas which were marginal for production had been spared by the complexities of acquiring a deforestation license, along with relatively low commodity prices. Since COVID-19, however, commodity prices have risen significantly and marginal areas have become quite profitable, increasing deforestation pressure in previously disregarded areas. Thus, the conservation of these forest assets becomes even more important in the context of higher deforestation pressure and urgency to mitigate climate change. To jump ahead and begin testing our hypothesis, addressing the lack of positive incentives, we built CONSERV, a mechanism that has the potential to avoid legal deforestation and its associated emissions.

\section{DATA AVAILABILITY STATEMENT}

The raw data supporting the conclusions of this article will be made available by the authors, without undue reservation.

\section{AUTHOR CONTRIBUTIONS}

MS: conceptualization, data analysis, methodology, writing, reviewing, and coordination. AGa and CS: data analysis, writing, and reviewing. $\mathrm{GB}$ and $\mathrm{AGu}$ : conceptualization and reviewing. PM: conceptualization, writing, and reviewing. All authors contributed to the article and approved the submitted version. 


\section{FUNDING}

We would like to acknowledge the financial support from Norway's International Climate and Forest Initiative (NICFI) through grant BRA-19/0009 and from the Ministry of Foreign Affairs from the Netherlands through the grant 4000003512 .

\section{REFERENCES}

Abadie, A., Diamond, A., and Hainmueller, A. J. (2010). Synthetic control methods for comparative case studies: estimating the effect of California's Tobacco control program. J. Am. Stat. Assoc. 105, 493-505. doi: 10.1198/jasa.2009. ap08746

Abadie, A., Diamond, A., and Hainmueller, J. (2015). Comparative Politics and the Synthetic Control Method. Am. J. Pol. Sci. 59, 495-510. doi: 10.1111/ajps.12116

Albuquerque, I., Alencar, A., Angelo, C., Azevedo, T., Barcellos, F., Coluna, I., et al. (2020). SEEG 8: Análise Das Emissões Brasileiras de Gases de Efeito Estufa e Suas Implicações Para as Metas de Clima do Brasil (1970-2019). Available Online at: https://www.oc.eco.br/wp-content/uploads/2020/12/OC_ RelatorioSEEG2020 final.pdf (accessed November 4, 2021).

Agência Nacional de Águas [ANA] (2018). Base Hidrográfica Ottocodificada 1:250.000. América: Agência Nacional de Águas

Azevedo, A. A., Rajão, R., Costa, M. A., Stabile, M. C. C., Macedo, M. N., dos Reis, T. N. P., et al. (2017). Limits of Brazil's Forest Code as a means to end illegal deforestation. Proc. Natl. Acad. Sci U S A. 114, 7653-7658. doi: 10.1073/pnas. 1604768114

Barnaud, C., and Antona, M. (2014). Deconstructing ecosystem services: uncertainties and controversies around a socially constructed concept. Geoforum 56, 113-123. doi: 10.1016/j.geoforum.2014.07.003

Bleischwitz, R., Hoff, H., Spataru, C., Van Der Voet, E., and VanDeveer, S. D. (2017). Routledge Handbook of the Resource Nexus. Abingdon: Routledge.

Börner, J., Baylis, K., Corbera, E., Ezzine-de-Blas, D., Honey-Rosés, J., Persson, U. M., et al. (2017). The Effectiveness of payments for Environmental Services. World Dev. 96, 359-374. doi: 10.1016/j.worlddev.2017.03.020

Brasil (2012). Lei $N^{\circ}$ 12.651, de 25 de Maio de 2012, Dispõe sobre a Proteção da Vegetação nativa. Available online at: http://www.planalto.gov.br/ccivil_03/ _Ato2011-2014/2012/Lei/L12651.htm (accessed November 4, 2021).

Brasil (2015). Intended Nationally Determined Contribution: Towards Achieving the Objective of the United Nations Framework Convention on Climate Change. Avaliable online at: https://www4.unfccc.int/sites/ndcstaging/PublishedDocuments/Brazil\%20First /BRAZIL\%20iNDC\%20english\%20FINAL.pdf (accessed January 16, 2022).

Brasil (2021). Lei $N^{\circ}$ 14.119, de 13 de Janeiro de 2021, Institui a Política Nacional de Pagamento Por Serviços Ambientais. Available online at: http://www.planalto. gov.br/ccivil_03/_Ato2019-2022/2021/Lei/L14119.htm (accessed November 4, 2021).

Cavender-Bares, J., Arroyo, M. T. K., Abell, R., Ackerly, D., Ackerman, D., Arim, M., et al. (2018). "Chapter 3: Status, trends and future dynamics of biodiversity and ecosystems underpinning nature's contributions to people," in The IPBES Regional Assessment Report on Biodiversity and Ecosystem Services for the Americas, eds M. Rounsevell., M. Fischer., A. Torre-Marin Rando., and A. Mader. (Germany: Biodiversity and Ecosystem Services), 71-293.

Chomitz, K. M., Thomas, T. S., and Brandao, A. S. (2004). Creating Markets for Habitat Conservation when Habitats are Heterogeneous World Bank Policy Res. Work. Pap 3429. Washington, DC: World Bank.

Coe, M. T., Brando, P. M., Deegan, L. A., Macedo, M. N., Neill, C., and Silvério, D. V. (2017). The Forests of the Amazon and Cerrado Moderate Regional Climate and Are the Key to the Future. Trop. Conserv. Sci. 10:194008291772067. doi: 10.1177/1940082917720671

Donofrio, S., Maguire, P., Zwick, S., and Merry, W. (2020). Voluntary Carbon and the Post-Pandemic Recovery. A Special Climate Week NYC 2020 Installment of Ecosystem Marketplace's State of Voluntary Carbon Markets 2020 Report. For. Trends. Avaliable online at: https://www.forest-trends.org/publications/stateof-the-voluntary-carbon-markets-2020-2/ (accessed January 16, 2022).

\section{ACKNOWLEDGMENTS}

We would like to thank other current and former staff members from IPAM who contributed in the conceptualization of CONSERV and who contributed to the early stage of this work. We would also like to thank Patrick Connerton for general language revisions.

Fundação Brasileira and Desenvolvimento Sustentável [FBDS] (2021). Mapeamento em Alta Resolução dos Biomas Brasileiros. Available online at: https://geo.fbds.org.br/ [accessed on Oct 27, 2021].

Freitas, F. L. M., Sparovek, G., Berndes, G., Persson, U. M., Englund, O., Barretto, A., et al. (2018). Potential increase of legal deforestation in Brazilian Amazon after Forest Act revision. Nat. Sustain. 1, 665-670. doi: 10.1038/s41893-0180171-4

Gatti, L. V., Basso, L. S., Miller, J. B., Gloor, M., Gatti Domingues, L., Cassol, H. L. G., et al. (2021). Amazonia as a carbon source linked to deforestation and climate change. Nature 595, 388-393. doi: 10.1038/s41586-021-03629-6

Instituto Nacional de Colonização e Reforma Agrária [INCRA] (2021). Acervo Fundiário. Available online at: http://certificacao.incra.gov.br/csv_shp/export_ shp.py (accessed March 10, 2021).

Instituto Nacional de Pesquisas Espaciais [INPE] (2021)). TerraBrasilis Plataforma de monitoramento. Available online at: http://terrabrasilis.dpi.inpe. br/ [accessed on Oct 27, 2021]

Jayachandran, S., De Laat, J., Lambin, E. F., Stanton, C. Y., Audy, R., and Thomas, N. E. (2017). Cash for carbon: arandomized trial of payments for ecosystem services to reduce deforestation. Science 357, 267-273. doi: 10.1126/science. aan0568

Leite-Filho, A. T., Soares-Filho, B. S., Davis, J. L., Abrahão, G. M., and Börner, J. (2021). Deforestation reduces rainfall and agricultural revenues in the Brazilian Amazon. Nat. Commun. 12:2591. doi: 10.1038/s41467-021-22 840-7

Liu, J., Mooney, H., Hull, V., Davis, S. J., Gaskell, J., Hertel, T., et al. (2015). Systems integration for global sustainability. Science 347:1258832. doi: 10.1126/science. 1258832

MapBiomas (2020). Mapeamento Anual da Cobertura e Uso do Solo no Brasil. Available Online at: https://mapbiomas.org/ [accessed on Oct 27, 2021].

MapBiomas Alerta (2020). MapBiomas Alert points out that 95\% of the deforestation detected in the country in 2019 was not authorized. Available online at: http: //alerta.mapbiomas.org/en/news [accessed on Oct 27, 2021]

MCTI (2021). SIRENE - Sistema de Registro Nacional de Emissões. Available Online at https://www.gov.br/mcti/pt-br/acompanhe-o-mcti/sirene (accessed November 4, 2021).

Observatório do Código Florestal [OCF] (2021). Termometro do Código Florestal. Available Online at: http://termometrocodigoflorestal.surge.sh/plataforma (accessed January 16, 2022).

Phillips, O. L., Brienen, R. J. W., Gloor, E., Baker, T. R., Lloyd, J., Lopez-Gonzalez, G., et al. (2017). Carbon uptake by mature Amazon forests has mitigated Amazon nations' carbon emissions. Carbon Balance Manag. 12:1. doi: 10.1186/ s13021-016-0069-2

Rajão, R., Soares-Filho, B., Nunes, F., Börner, J., Machado, L., Assis, D., et al. (2020). The rotten apples of Brazil\&\#039;s agribusiness. Science 369:246. doi: $10.1126 /$ science.aba6646

Rizzo, R., Garcia, A. S., Ballester, M. V. R., Victoria, D. C., Neill, C., and Rocha, H. R. D. (2020). Land use changes and alteration in water resources of southeastern Amazon: trends in rainfall, temperature and river discharge during 1976-2015. Clim. Chang. 162, 1419-1436. doi: 10.1007/s10584-02002736-z

Rosenbaum, P. R., and Rubin, D. B. (1983). The central role of the propensity score in observational studies for causal effects. Biometrika 70, 41-55. doi: 10.1093/biomet/70.1.41

Rubin, D. B. (1974). Estimating causal effects of treatments in randomized and non-randomized studies. J. Educ. Psychol. 66, 688-701. doi: 10.1037/h0037350

Sampaio, G., Nobre, C., Costa, M. H., Satyamurty, P., Soares-Filho, B. S., and Cardoso, M. (2007). Regional climate change over eastern Amazonia caused 
by pasture and soybean cropland expansion. Geophys. Res. Lett. 34:17. doi: 10.1029/2007GL030612

Serviço Florestal and Brasileiro [SFB] (2021). SICAR - Sistema Nacional de Cadastro Ambiental Rural. Available Online at: http://www.car.gov.br/publico/ imoveis/index (accessed March 10, 2021).

Silvério, D. V., Brando, P. M., Macedo, M. N., Beck, P. S. A., Bustamante, M., and Coe, M. T. (2015). Agricultural expansion dominates climate changes in southeastern Amazonia: the overlooked nonGHG forcing. Environ. Res. 10:10. doi: 10.1088/1748-9326/10/10/10 4015

Soares-Filho, B., Rajao, R., Macedo, M., Carneiro, A., Costa, W., Coe, M., et al. (2014). Cracking Brazil's Forest Code. Science 344, 363-364. doi: 10.1126/ science. 1246663

Spera, S. A., Galford, G. L., Coe, M. T., Macedo, M. N., and Mustard, J. F. (2016). Land-use change affects water recycling in Brazil's last agricultural frontier. Glob. Chang. Biol. 22, 3405-3413. doi: 10.1111/gcb.1 3298

Vasconcelos, A., Bernasconi, P., Guidotti, V., Silgueiro, V., Valdiones, A., Carvalho, T., et al. (2020). Illegal Deforestation and Brazilian Soy Exports: The Case of Mato Grosso. Trase. Earth. Avaliable online at: https://insights.trase.earth/ publications/ (accessed January 16, 2022).
West, T. A. P., Börner, J., Sills, E. O., and Kontoleon, A. (2020). Overstated carbon emission reductions from voluntary REDD + projects in the Brazilian Amazon. Proc. Natl. Acad. Sci. U S A. 117, 24188-24194. doi: 10.1073/pnas.2004334117

Conflict of Interest: The authors declare that the research was conducted in the absence of any commercial or financial relationships that could be construed as a potential conflict of interest.

Publisher's Note: All claims expressed in this article are solely those of the authors and do not necessarily represent those of their affiliated organizations, or those of the publisher, the editors and the reviewers. Any product that may be evaluated in this article, or claim that may be made by its manufacturer, is not guaranteed or endorsed by the publisher.

Copyright (c) 2022 Stabile, Garcia, Salomão, Bush, Guimarães and Moutinho. This is an open-access article distributed under the terms of the Creative Commons Attribution License (CC BY). The use, distribution or reproduction in other forums is permitted, provided the original author(s) and the copyright owner(s) are credited and that the original publication in this journal is cited, in accordance with accepted academic practice. No use, distribution or reproduction is permitted which does not comply with these terms. 